\title{
Sero-prevalence of HTLV $1 / 2$ and HCV in paired mother and children from Malawi as well as systematic review and meta-analysis of HTLV-1/2 and HCV of data available on women and children living in Africa
}

\author{
James M Fox ${ }^{1}$, Robert Newton², Marija Bedaj ${ }^{1}$, John Martin Bland ${ }^{2}$, Nora Mutalima², Fabiola Martin ${ }^{1 *}$ \\ From 16th International Conference on Human Retroviruses: HTLV and Related Viruses \\ Montreal, Canada. 26-30 June 2013
}

HTLV prevalence is poorly mapped in several areas, in particular in Africa. Global prevalence is commonly cited as being 10-20 million but more recently this has been contested as an overestimation. Additional epidemiological studies would further our understanding of the HTLV burden. Similarly, $\mathrm{HCV}$ is endemic in certain locations (Egypt) whilst data for other areas of Africa are virtually absent. We investigated HTLV/HCV prevalence in serum samples from 418 paired mother and child samples of healthy mothers of children attending Malawian hospitals. Latest generation ELISAs were used; consistently ELISA reactive mothers' sera were further tested by immunoblot and only deemed sero-positive if they were reactive in this assay. Serum from the children of ELISA positive/borderline mothers were subsequently screened. Sero-prevalence in the healthy women was as follows, HTLV-1: 0.72\% $(\mathrm{n}=3)$, HTLV-2: $1.9 \%(\mathrm{n}=8)$, HTLV indeterminate: $3.8 \%$ $(n=16)$ and HCV: $0.48 \%(n=2)$. DNA extracted from whole blood could only resolve one of the high percentage of intermediate positive results, most likely because of a low proviral load. One child in each category: HTLV-1, HTLV-2, dual-infected and HTLV indeterminate was identified indicating low (11.54\%) mother to child transmission (MTCT) whereas one of the two $\mathrm{HCV}$ positive mothers had a HCV positive child, suggestive of high HCV MTCT transmission rate. We conducted a systematic review to compare this original data with previous

\footnotetext{
*Correspondence: fabiola.martin@hyms.ac.uk

'Centre for Immunology and Infection, Department of Biology \& Hull York Medical School, University of York, York, North Yorkshire, UK Full list of author information is available at the end of the article
}

reports: Malawi had similar, low, levels of HTLV-1 and HCV but surprisingly high HTLV-2. Prevalence maps for HTLV and HCV for this demographic in the African continent and the meta-analysis will be presented.

\section{Authors' details}

${ }^{1}$ Centre for Immunology and Infection, Department of Biology \& Hull York Medical School, University of York, York, North Yorkshire, UK. ${ }^{2}$ Department of Health Sciences, University of York, York, North Yorkshire, UK.

Published: 7 January 2014

doi:10.1186/1742-4690-11-S1-P58

Cite this article as: Fox et al: Sero-prevalence of HTLV $1 / 2$ and HCV in paired mother and children from Malawi as well as systematic review and meta-analysis of HTLV-1/2 and HCV of data available on women and children living in Africa. Retrovirology 2014 11(Suppl 1):P58.

Submit your next manuscript to BioMed Central and take full advantage of:

- Convenient online submission

- Thorough peer review

- No space constraints or color figure charges

- Immediate publication on acceptance

- Inclusion in PubMed, CAS, Scopus and Google Scholar

- Research which is freely available for redistribution 